\title{
KAPASITAS STRUKTUR KOLOM PIPIH BETON BERTULANG PADA PERUMAHAN VILLA ANGGREK KOTA PEKANBARU
}

\author{
(Capacity of Flat Coloumn Reinforced Concrete Structures in Residential \\ Villa Anggrek Pekanbaru City)
}

\author{
Shanti Wahyuni Megasari ${ }^{1}$, Gusneli Yanti ${ }^{1}$ Zainuri $^{1}$ \\ ${ }^{1}$ Program Studi Teknik Sipil Universitas Lancang Kuning \\ E-mail: shanti@unilak.ac.id
}

Diterima 12 Oktober 2020, Disetujui 27 Oktober 2020

\begin{abstract}
ABSTRAK
Renovasi pada bangunan struktur dengan penambahan tingkat pada bangunan dan terjadinya perubahan fungsi lantai existing serta perkuatan yang dilaksanakan pada kolom exsisting dapat menyebabkan terjadinya perubahan kapasitas struktur bangunan secara keseluruhan. Selain itu pemanfaatan kolom pipih dengan dimensi kolom yang dibuat sama rata dengan dinding akan lebih baik dari segi estetika, namun kolom tersebut harus tetap mampu memikul beban yang bekerja. Sehingga diperlukan penelitian kapasitas struktur kolom pipih pada Perumahan Villa Anggrek. Perancangan dan analisa struktur bangunan beton bertulang dengan bantuan program ETABS v16.2.0, SAFE 16.0.1 serta SPcolumn v.6.0 dan kemudian dikontrol secara manual berdasarkan SNI 03-2847-2013. Dalam pelaksanaan dilakukan 2 (dua) perhitungan yaitu pada elemen struktur existing dan pada struktur rencana. Dari hasil analisis dapat disimpulkan bahwa kapasitas struktur existing dan rencana yang menggunakan struktur kolom pipih beton bertulang pada perumahan Villa Anggrek Kota Pekanbaru aman untuk menerima kombinasi beban sesuai SNI 2847-2013. Serta pemanfaatan kolom pipih dengan dimensi kolom dibuat rata sama dinding sehingga akan lebih baik di pandang dari segi estetika namun tetap mampu memikul beban yang bekerja.
\end{abstract}

Kata Kunci: Existing, Kapasitas, Kolom Pipih, Rencana, Struktur

\begin{abstract}
Renovation of structural buildings with additional levels of the building and changes in the function of the existing floors and strengthening of the existing columns can cause changes in the overall capacity of the building structure. Besides, the use of flat columns with the dimensions of the columns that are made flush with the walls will be better in terms of aesthetics, but the column must still be able to bear the load that works. So it is necessary to research the capacity of the flat column structure at Residential Villa Anggrek. Design and analysis of reinforced concrete building structures with the help of the ETABS v16.2.0, SAFE 16.0.1, and SPcolumn v.6.0 programs and then manually controlled based on SNI 032847-2013. In the implementation, 2 (two) calculations are carried out, namely on the existing structural elements and the plan structure. From the results of the analysis, it can be concluded that the capacity of the existing and planned structures that use the reinforced concrete flat column structure at the Residential Villa Anggrek, Pekanbaru City is safe to accept the load combination according to SNI 28472013. As well as the use of flat columns with the dimensions of the column made flat against the walls so that it will be better in terms of aesthetics but still able to bear the workload. As well as the use of flat columns with the dimensions of the column made flat against the walls so that it will be better in terms of aesthetics but still able to bear the workload.
\end{abstract}

Keywords: Existing, Capacity, Flat Column, Plan, Structure 


\section{PENDAHULUAN}

Salah satu faktor utama dalam perencanaan suatu struktur bangungan adalah tahapan perhitungan pembebanan. Dimana perlu dilakukan perhitungan dengan baik jenis beban yang akan dipikul oleh struktur sesuai dengan fungsi dari bangunan tersebut.

Perumahan Villa Anggrek dibangun pada tahun 2010 yang dengan tipe 45 yang terdiri dari bangunan 1 lantai. Pada tahun 2019 akan dilakukan renovasi pada perumahan tersebut, dimana bangunan tersebut akan ditingkatkan dari bangunan 1 lantai menjadi 2 lantai.

Selain penambahan tingkat pada bangunan, pada perumahan tersebut juga direncanakan untuk melakukan perubahan fungsi pelat pada lantai 1. Pelat pada lantai 1 yang semula sebagai pelat atap berubah fungsi menjadi pelat lantai ruang kamar tidur. Sesuai dengan SNI 1727: 2013, perubahan pada fungsi bangunan akan menyebabkan terjadinya perubahan beban hidup. Beban hidup pelat atap semula bernilai $0,96 \mathrm{kN} / \mathrm{m}^{2}$ sedangkan untuk hunian rumah tinggal bernilai $1,92 \mathrm{kN} / \mathrm{m}^{2}$.

Pada renovasi Perumahan Villa Anggrek akan menggunakan konsep minimalis dengan menggunakan kolom pipih. Kolom pipih adalah kolom yang direncanakan untuk tidak melebihi tebal dari dinding ruangan. Nilai estetika sangat dikedepankan pada pemilihan penggunaan kolom pipih karena menyebabkan kolom menjadi rata dengan dinding dan memberikan kesan ruangan menjadi lebih luas.

Kolom pipih memiliki bentuk persegi panjang, berbentuk $L$ pada bagian tepi ujung denah dan bentuk $\mathrm{T}$ pada bagian tepi tengah bangunan (Roring, Y., dkk, 2016). Kolom penampang pipih memiliki perbedaan kekakuan yang besar dalam kedua arah sumbu utamanya sehingga sangat berpengaruh terhadap integritas struktur secara keseluruhan (Limbongan, S.,dkk, 2016) Serta bentuk penampang kolom berbentuk pipih akan memberikan hasil berbeda dengan bentuk penampang kolom pada umumnya, karena kolom pipih mempunyai titik berat yang berbeda.

Selain itu, dalam tahapan pengerjaan kolom di lapangan juga tidak bisa langsung dilaksanakan pekerjaan tingkat atas. Dikarenakan kekhawatiran akan kekuatan kolom pada lantai 1 yang semula direncanakan hanya untuk bangunan 1 lantai. Sehingga beberapa bagian kolom lama harus ditambahkan dimensi serta penulangannya. Hal ini tentu saja akan berpengaruh terhadap kapasitas struktur secara keseluruhan. Sehingga diperlukan perhitungan kapasitas struktur kolom pipih dan kapasitas struktur secara keseluruhan pada Perumahan
Villa Anggrek.

\section{METODE}

Material yang digunakan adalah beton bertulang dengan spesifikasi sebagai berikut :

1. Beton K-225 Weight Unit per Volume : $24 \mathrm{kN} / \mathrm{m}^{3}$ Kuat tekan silinder (fc') : 18,31 MPa Modulus elastisitas (Ec) : 20113,8983 $\mathrm{MPa}$

2. Baja tulangan

$\begin{array}{ll}\text { Weight Unit per Volume } & : 78,5 \mathrm{kN} / \mathrm{m}^{3} \\ \text { Kuat leleh (fy) BJTP } & : 295 \mathrm{MPa} \\ \text { Kuat leleh (fy) BJTS } & : 345 \mathrm{MPa} \\ \text { Kuat leleh (fy) BJTP } & : 240 \mathrm{MPa} \\ \text { Modulus elastisitas (Es) } & : 200.000\end{array}$

$\mathrm{MPa}$

3. Dimensi elemen struktur balok

Pada perencanaan ini dimensi balok mempunyai 4 tipe yaitu :
Balok tipe B1
: $13 \times 30 \mathrm{~cm}$ (existing)
Balok tipe B2
: $13 \times 25 \mathrm{~cm}$ (existing)
Balok tipe B3
: $13 \times 30 \mathrm{~cm}$ (rencana)
Balok tipe B4
: $13 \times 25 \mathrm{~cm}$ (rencana)

Posisi balok dapat dilihat pada Gambar 1 dan 2.

4. Dimensi elemen struktur kolom

Pada perencanaan ini dimensi kolom mempunyai 5 tipe sebagai berikut :

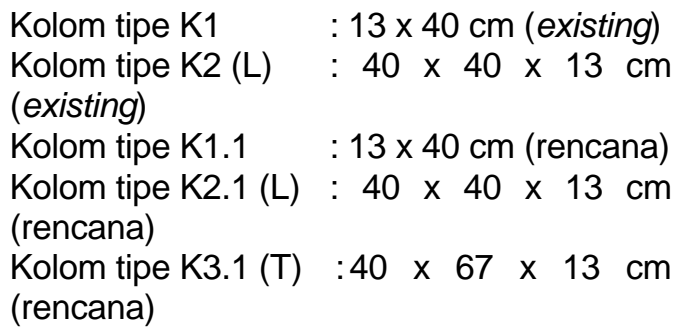

Posisi kolom dapat dilihat pada Gambar 3 dan 4. Sedangkan detail penampang kolom pipih dapat dilihat pada Gambar 5. 


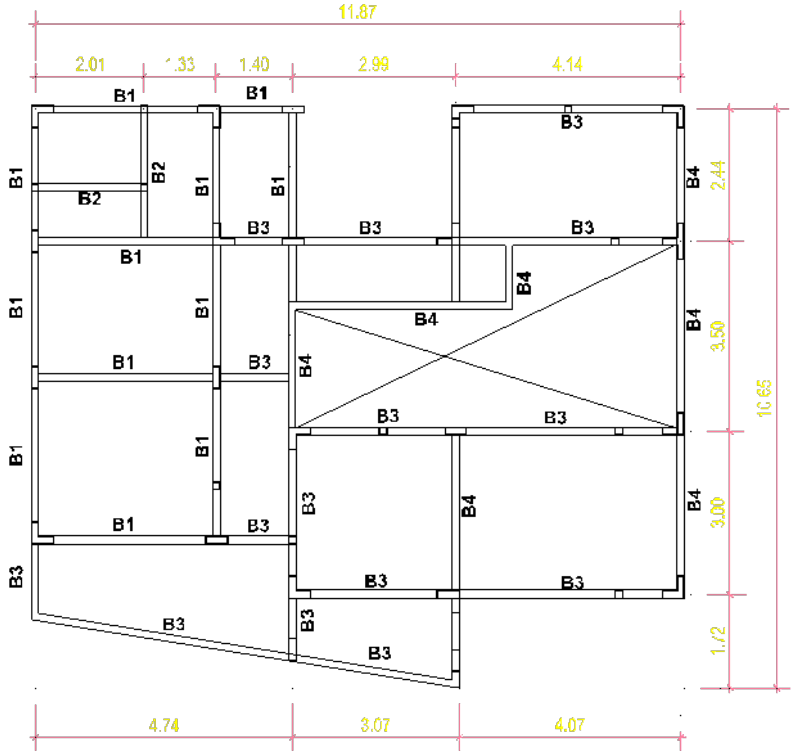

Gambar 1. Denah Posisi Balok Lantai 1

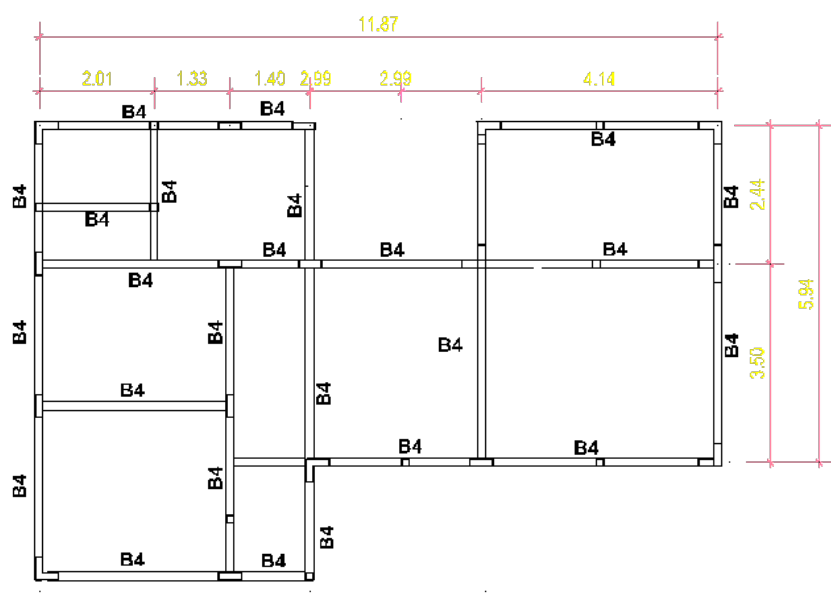

Gambar 2. Denah Posisi Balok Lantai 2

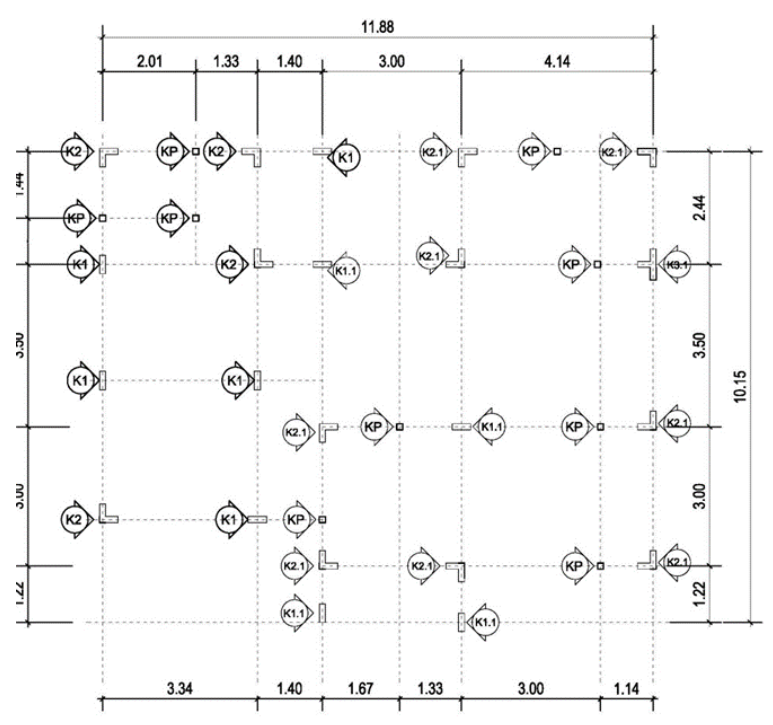

Gambar 3. Denah Posisi Kolom Lantai 1

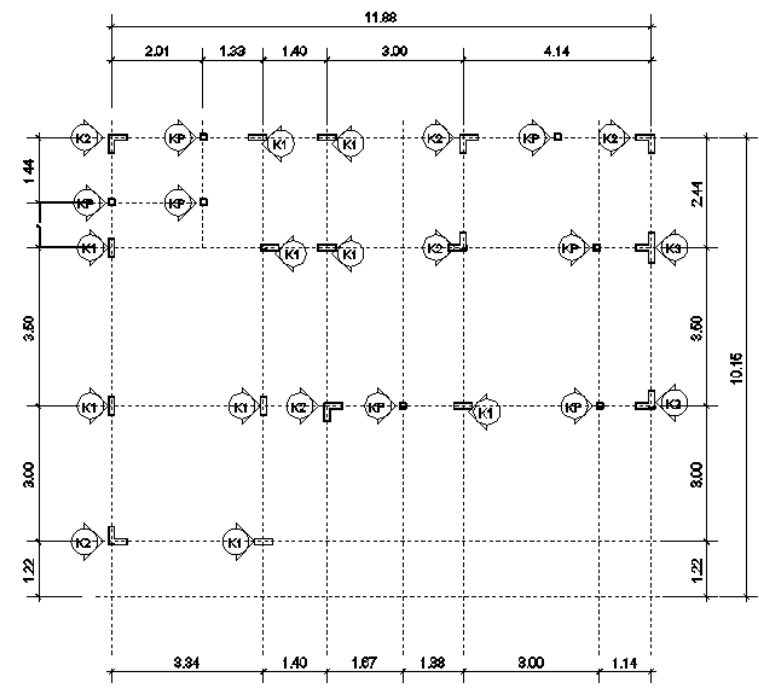

Gambar 4. Denah Posisi Kolom Lantai 2

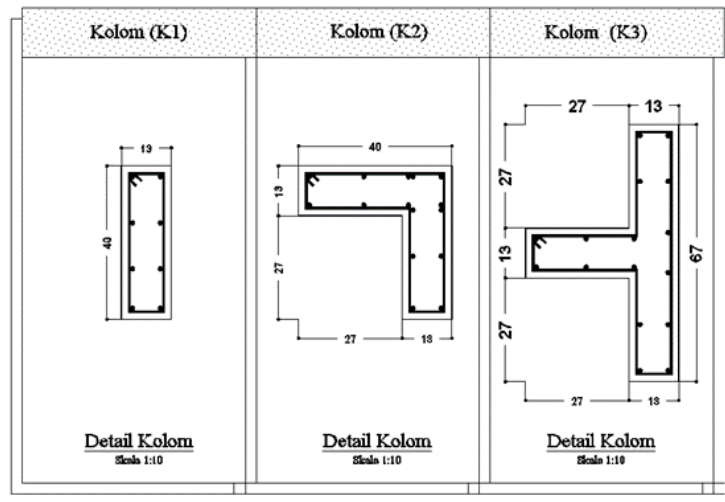

Gambar 5. Detail Penampang Kolom Pipih

5. Dimensi elemen struktur pelat

Pelat Lantai $\quad: 12 \mathrm{~cm}$

Pelat atap atau dag $\quad: 10 \mathrm{~cm}$

Setelah data yang diperoleh secara keseluruhan, perancangan dan analisa struktur bangunan beton bertulang 3 dimensi dengan bantuan program ETABS v16.2.0, SAFE 16.0.1 untuk perhitungan kekuatan kolom menggunakan program SPcolumn v.6.0, di kontrol secara manual berdasarkan SNI 03-2847-2013.

Dalam pelaksanaan dilakukan 2 (dua) tahapan perhitungan yaitu pada elemen struktur existing dan pada struktur rencana.

\section{HASIL DAN PEMBAHASAN}

Penentuan dimensi elemen-elemen struktur yang digunakan baik itu balok, kolom, pelat lantai serta pembebanan struktur, mengacu pada SNI 2847:2013, Asroni, A., (2010), Imran, I dan Zulkifli, E., (2014), Dewobroto, W., (2013) serta Setiawan, A., (2016). 


\section{Pemodelan struktur}

Pembebanan meliputi beban mati dan beban hidup, beban mati terdiri dari 2 jenis yaitu beban mati sendiri elemen struktur dan beban mati akibat gaya luar. Beban mati sendiri elemen struktur yang terdiri dari kolom, balok, dan plat sudah dihitung secara otomatis dalam ETABS v.16.2.0. Pemodelan struktur dapat dilihat pada gambar 6 .

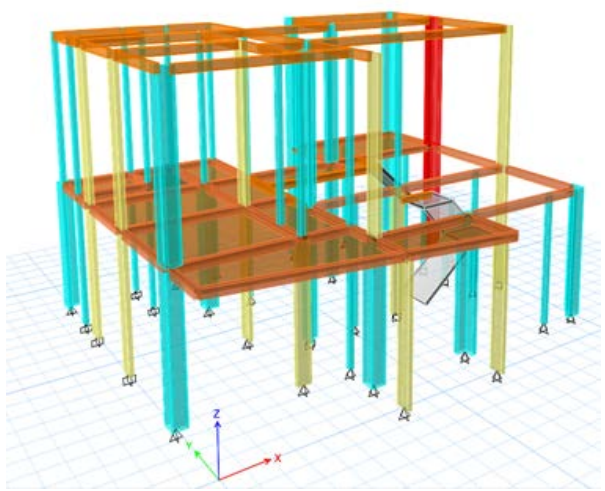

Gambar 6. Pemodelan Struktur

Kapasitas dan perencanaan struktur pada bangunan ini didasari terhadap beban mati dan hidup yang telah diatur di dalam SNI 1727: 2013 tentang beban minimum untuk perencanaan bangunan gedung dan struktur lain, dimana untuk analisis struktur menggunakan program komputer. Yang terdiri dari ETABS V.6.2.0

\section{Kapasitas struktur existing}

a. Elemen pelat lantai

Untuk analisis gaya dalam elemen pelat menggunakan program komputer SAFE V.16.0.1. Pengecekan kapasitas existing pelat lantai yang ditinjau adalah pelat dengan ukuran $\mathrm{Ix}=3,34 \mathrm{~m} \times \mathrm{ly}=2,98 \mathrm{~m}$ yang terletak pada lantai 1 yang berfungsi sebagai kamar tidur. Kapasitas elemen pelat existing dapat dilihat pada tabel 1.

Tabel 1. Kapasitas Elemen Pelat Lantai Existing

\begin{tabular}{|c|c|c|c|c|c|}
\hline \multicolumn{2}{|c|}{ Lokasi } & $\begin{array}{c}\mathrm{Mu} \\
(\mathrm{kN} \cdot \mathrm{m})\end{array}$ & $\begin{array}{l}A_{s \text { pakai }} \\
\left(\mathrm{mm}^{2}\right)\end{array}$ & Tulangan terpasang & $\begin{array}{c}\phi \mathrm{Mn} \\
\text { (kN.mm) }\end{array}$ \\
\hline \multirow[t]{2}{*}{ Tump. X } & Pokok & 8,269 & 523,60 & $\varnothing 10-150$ & 12,52 \\
\hline & Susut & & 314,16 & $\varnothing 10-250$ & \\
\hline \multirow[t]{2}{*}{ Lap. X } & Pokok & 9,393 & 523,60 & $\varnothing 10-150$ & 12,52 \\
\hline & Susut & & 314,16 & $\varnothing 10-250$ & \\
\hline \multirow[t]{2}{*}{ Tump. Y } & Pokok & 6,094 & 523,60 & $\varnothing 10-150$ & 11,13 \\
\hline & Susut & & 314,16 & $\varnothing 10-250$ & \\
\hline \multirow[t]{2}{*}{ Lap. Y } & Pokok & 4,181 & 523,60 & $\varnothing 10-150$ & 11,13 \\
\hline & Susut & & 314,16 & $\varnothing 10-250$ & \\
\hline
\end{tabular}

Pada analisis kapasitas elemen pelat existing, diperoleh momen nominal lebih besar dari pada momen ultimit atau momen lentur terfaktor $\mathrm{Mu}<$ momen nominal $\phi \mathrm{Mn}$, sehingga dapat dinyatakan bahwa seluruh elemen pelat existing memenuhi persyaratan SNI 2847:2013 pasal 9.1.1. b. Elemen balok

Dalam analisis kapasitas digunakan momen maksimum pada elemen balok. Pengecekan kapasitas existing balok yang ditinjau adalah balok dengan ukuran 13/30 dan 13/25 yang terletak pada lantai 1. Kapasitas lentur elemen balok existing dapat dilihat pada Tabel 2 dan kapasitas geser elemen balok existing dapat dilihat pada Tabel 3.

Tabel 2. Kapasitas Lentur Elemen Balok Existing

\begin{tabular}{llllll}
\hline Tipe Balok & Lokasi & $\begin{array}{l}\text { Mu } \\
(\mathrm{kN} . \mathrm{m})\end{array}$ & $\begin{array}{l}\mathrm{A}_{\text {s pakai }} \\
\left(\mathrm{mm}^{2}\right)\end{array}$ & Tulangan terpasang & $\begin{array}{l}\phi M n \\
(\mathrm{kN} . \mathrm{m})\end{array}$ \\
\hline $13 / 30$ & Tump. (Negatif) & 12,80 & 226,19 & 2 D12 & 14,98 \\
& Tump. (Positif) & - & 226,19 & 2 D12 & - \\
& Lap. (Negatif) & - & 226,19 & 2 D12 & - \\
& Lap. (Positif) & 11,15 & 226,19 & 2 D12 & 14,98 \\
\hline $13 / 25$ & Tump. (Negatif) & 0,42 & 157,08 & 2 D10 & 8,57 \\
& Tump. (Positif) & - & 157,08 & 2 D10 & - \\
& Lap (Negatif) & - & 157,08 & 2 D10 & - \\
& Lap. (Positif) & 1,32 & 157,08 & 2 D10 & 8,57 \\
\hline
\end{tabular}


Tabel 3. Kapasitas Geser Elemen Balok Existing

\begin{tabular}{llllll}
\hline Type Balok & Lokasi & $\begin{array}{l}\mathrm{Vu} \\
(\mathrm{kN})\end{array}$ & $\begin{array}{l}\mathrm{A}_{\mathrm{s} \text { pakai }} \\
\left(\mathrm{mm}^{2}\right)\end{array}$ & $\begin{array}{l}\text { Tulangan } \\
\text { terpasang }\end{array}$ & $\begin{array}{l}\phi \mathrm{Vn} \\
(\mathrm{kN})\end{array}$ \\
\hline $13 / 30$ & Tumpuan & 30,11 & 100,5 & $\varnothing 8-150$ & 50,59 \\
$13 / 25$ & Tumpuan & 02,11 & 100,5 & $\varnothing 8-150$ & 41,28 \\
\hline
\end{tabular}

c. Elemen kolom pipih

Dalam analisis kapasitas digunakan momen maksimum pada elemen kolom. Pengecekan kapasitas elemen kolom existing dilakukan dengan program spColumn V6.0. Tulangan yang digunakan pada elemen kolom existing dapat dilihat pada tabel 4 .

Tabel 4. Penulangan Elemen Kolom Existing

\begin{tabular}{cccc}
\hline Lantai & $\begin{array}{c}\text { Tipe } \\
\text { Kolom }\end{array}$ & $\begin{array}{c}\text { Tulangan } \\
\text { Longitudinal }\end{array}$ & $\begin{array}{c}\text { Tulangan } \\
\text { sengkang }\end{array}$ \\
\hline Lantai 1 & K1 & 8 D10 & $\varnothing 8-150$ \\
& K2 & 13 D10 & $\varnothing 8-150$ \\
\hline
\end{tabular}

Pada tipe kolom $\mathrm{K} 1$ digunakan tulangan longitudinal 8D10 dan pada tipe kolom K2 digunakan tulangan longitudinal 13D10. Kapasitas aksial dan lentur elemen kolom existing dapat dilihat pada tabel 5.

Tabel 5. Kapasitas Aksial Dan Lentur Elemen Kolom Existing

\begin{tabular}{ccccccc}
\hline Tipe & \multicolumn{2}{c}{ Analisis struktur } & \multicolumn{3}{c}{ Kapasitas struktur } \\
\cline { 2 - 7 } Kolom & $\mathrm{Pu}$ & $\mathrm{Mu}(\mathrm{kN} . \mathrm{m})$ & \multicolumn{2}{c}{$\phi \mathrm{Pn}$} & \multicolumn{1}{c}{$\phi \mathrm{Mn}(\mathrm{kN} . \mathrm{m})$} \\
& $(\mathrm{KN})$ & & & $(\mathrm{KN})$ & & \\
& & $\mathrm{X}$ & $\mathrm{Y}$ & & $\mathrm{X}$ & $\mathrm{Y}$ \\
\hline $\mathrm{K} 1$ & 132,53 & 2,68 & 2,65 & 494,2 & 10,09 & 9,97 \\
$\mathrm{~K} 2$ & 178,22 & 3,66 & 15,56 & 824,10 & 10,11 & 43,00 \\
\hline
\end{tabular}

Diagram interaksi kolom pipih dengan aplikasi program spColumn dapat dilihat pada gambar 7 dan 8.

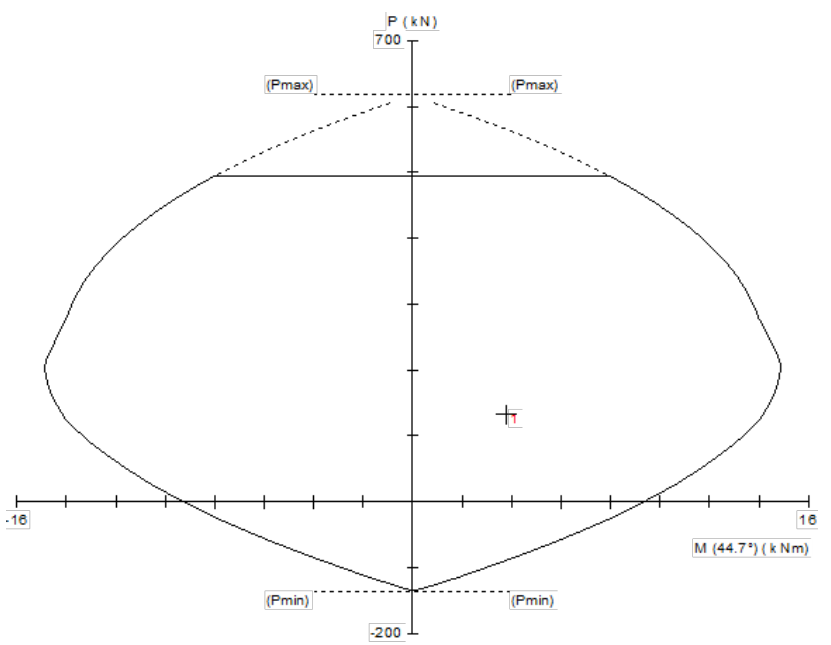

Gambar 7. Diagram Interaksi Kolom Pipih K1

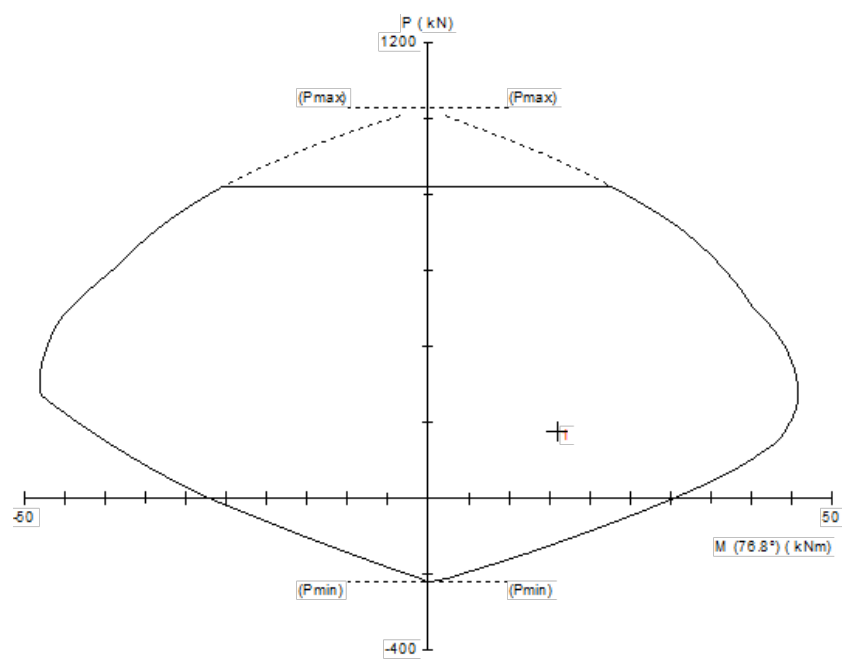

Gambar 8. Diagram Interaksi Kolom Pipih K2

Perhitungan kekuatan penampang kolom pipih K1 dan K2 menggunakan aplikasi spColumn V6.0 dengan menginput data-data berupa material, gaya aksial dan momen, kombinasi beban pada kolom berdasarkan SNI 2847: 2013 pasal 10.3.6, desain beban aksial aman apabila $\mathrm{Pu} \leq \phi \mathrm{Pn}$. Hasil output pada diagram interaksi kolom K1 dan K2 menunjukkan bahwa kolom pipih dapat memikul seluruh beban yang bekerja. Kolom pipih K1 dan K2 juga memiliki momen lentur terfaktor Mu<momen nominal $\phi M n$ sehingga aman memikul pembebanan yang terjadi.

Kapasitas geser elemen kolom existing dapat dilihat pada tabel 6 .

Tabel 6. Kapasitas Geser Elemen Kolom Existing

\begin{tabular}{cccccc}
\hline \multirow{2}{*}{ Tipe } & Tulangan & \multicolumn{2}{c}{$\begin{array}{c}\text { Analisis } \\
\text { struktur }\end{array}$} & \multicolumn{2}{c}{$\begin{array}{c}\text { Kapasitas } \\
\text { struktur }\end{array}$} \\
\cline { 3 - 6 } Kolom & sengkang & \multicolumn{2}{c}{$\mathrm{Vu}(\mathrm{kN})$} & \multicolumn{2}{c}{$\phi \vee \mathrm{Vn}(\mathrm{kN})$} \\
& & $\mathrm{X}$ & $\mathrm{Y}$ & $\mathrm{X}$ & $\mathrm{Y}$ \\
\hline $\mathrm{K} 1$ & $\varnothing 8-150$ & 4,17 & 3,04 & 15,56 & 143,39 \\
$\mathrm{~K} 2$ & $\varnothing 8-150$ & 8,12 & 2,26 & 74,11 & 74,11 \\
\hline
\end{tabular}

Setelah dilakukan pengecekan pada seluruh elemen struktur existing, diperoleh semua elemen existing yang terdiri dari pelat lantai, balok dan kolom memenuhi persyaratan SNI 2847: 2013, hal ini sama dengan penelitian yang telah dilakukan oleh Kadir, J.I., dkk, (2017). 
3. Kapasitas struktur rencana

Untuk bangunan yang akan direncanakan menjadi dua lantai akan di design sesuai dengan SNI 2847: 2013, agar dapat memenuhi kriteria dasar yaitu Kekuatan (tegangan), kekakuan (deformasi) serta daktilitas (perilaku keruntuhannya). a. Perencanaan elemen pelat lantai

Analisis perhitungan pelat lantai yang akan ditinjau adalah yang menghasilkan momen maksimum paling besar yang dapat dilihat pada tabel 1. Analisis perencanaan pelat lantai yang ditinjau adalah pelat dengan ukuran 4,14 $\mathrm{m} \times 2,44 \mathrm{~m}$ yang terletak pada lantai 1. Penulangan elemen pelat lantai rencana dapat dilihat pada Tabel 7.

Tabel 7. Penulangan Elemen Pelat Lantai Rencana

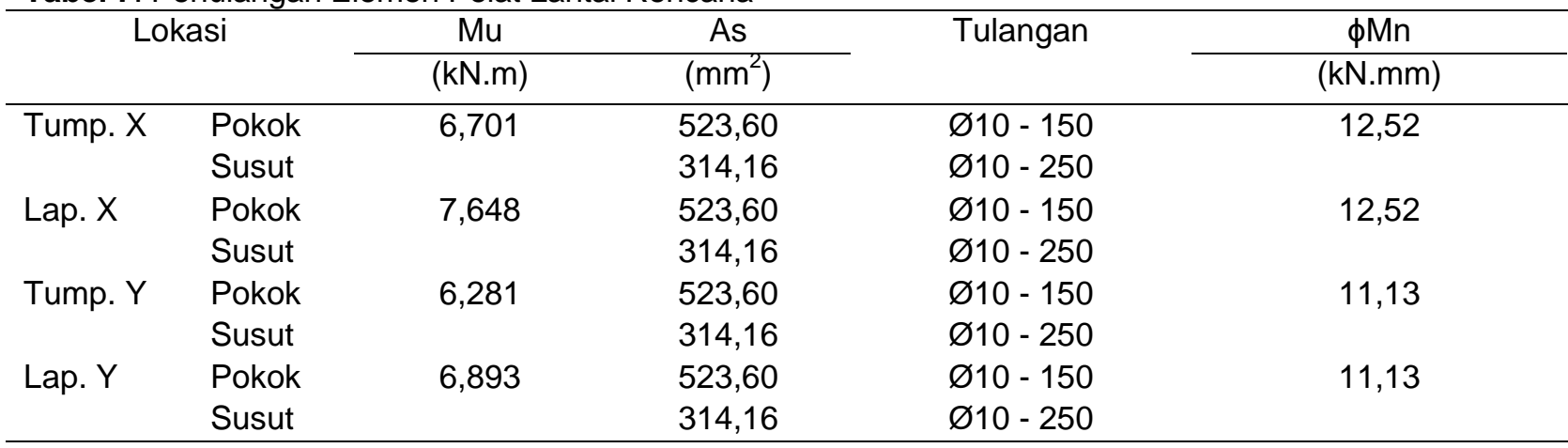

Analisis perhitungan pelat lantai yang akan ditinjau adalah yang menghasilkan momen maksimum paling besar yang dapat dilihat pada Tabel 1. Analisis perencanaan pelat atap yang ditinjau adalah pelat dengan ukuran 4,14 $\mathrm{m} \times 2,44 \mathrm{~m}$ yang terletak pada lantai 2. Penulangan elemen pelat atap rencana dapat dilihat pada tabel 8. b. Perencanaan elemen balok Analisis perencanaan balok B3 berdasarkan momen maksimum yang dapat dilihat pada tabel 2. Kapasitas lentur elemen balok rencana dapat dilihat pada tabel 9. Untuk kesuluran nilai dieroleh Mu< $\phi M n$, sehingga struktur aman untuk digunkaan. Kapasitas geser elemen balok rencana dapat dilihat pada tabel 10.

Tabel 8. Penulangan Elemen Pelat Atap Rencana

\begin{tabular}{|c|c|c|c|c|c|}
\hline \multicolumn{2}{|c|}{ Lokasi } & \multirow{2}{*}{$\frac{\mathrm{Mu}}{(\mathrm{kN} . \mathrm{m})}$} & \multirow{2}{*}{$\frac{\text { As }}{\left(\mathrm{mm}^{2}\right)}$} & \multirow[t]{2}{*}{ Tulangan } & \multirow{2}{*}{$\frac{\phi \mathrm{Mn}}{(\mathrm{kN} . \mathrm{mm})}$} \\
\hline & & & & & \\
\hline \multirow[t]{2}{*}{ Tump. X } & Pokok & 7,501 & 549,78 & $\varnothing 10-150$ & 9,74 \\
\hline & Susut & & 314.16 & $\varnothing 10$ - 250 & \\
\hline \multirow[t]{2}{*}{ Lap. X } & Pokok & 5,970 & 523.6 & $\varnothing 10$ - 150 & 9,74 \\
\hline & Susut & & 314.16 & $\varnothing 10$ - 250 & \\
\hline \multirow[t]{2}{*}{ Tump. Y } & Pokok & 7,350 & 523.6 & $\varnothing 10-150$ & 8,35 \\
\hline & Susut & & 314.16 & $\varnothing 10-250$ & \\
\hline \multirow[t]{2}{*}{ Lap. Y } & Pokok & 7,330 & 523.6 & $\varnothing 10$ - 150 & 8,35 \\
\hline & Susut & & 314.16 & $\varnothing 10$ - 250 & \\
\hline
\end{tabular}

Tabel 9. Kapasitas Lentur Elemen Balok Rencana

\begin{tabular}{clcccc}
\hline Tipe Balok & \multicolumn{1}{c}{ Lokasi } & $\begin{array}{c}\mathrm{Mu} \\
(\mathrm{kN} . \mathrm{m})\end{array}$ & $\begin{array}{c}\text { Kebutuhan } \\
\text { Tulangan }\end{array}$ & $\begin{array}{c}\mathrm{A}_{\mathrm{s}} \\
\left(\mathrm{mm}^{2}\right)\end{array}$ & $\begin{array}{c}\phi \mathrm{Mn} \\
(\mathrm{kN} . \mathrm{m})\end{array}$ \\
\hline \multirow{2}{*}{$13 / 30$} & Tump. (Negatif) & 15,45 & $2 \mathrm{D} 12$ & 266 & 17,19 \\
& Tump. (Positif) & - & $2 \mathrm{D} 12$ & 266 & - \\
& Lap. (Negatif) & - & $2 \mathrm{D} 10$ & 157 & - \\
& Lap. (Positif) & 11,15 & $2 \mathrm{D} 12$ & 266 & - \\
\hline \multirow{2}{*}{$13 / 25$} & Tump. (Negatif) & 4,65 & $2 \mathrm{D} 12$ & 266 & 17,19 \\
& Tump. (Positif) & - & $2 \mathrm{D} 10$ & 266 & 9,93 \\
& Lap (Negatif) & - & $2 \mathrm{D} 10$ & 266 & - \\
& Lap. (Positif) & 3,10 & $2 \mathrm{D} 10$ & 157 & - \\
\hline
\end{tabular}


Tabel 10. Kapasitas Geser Elemen Balok Rencana

\begin{tabular}{ccccccc}
\hline Tipe Balok & Lokasi & & $\begin{array}{c}\text { Vu } \\
(\mathrm{kN} . \mathrm{m})\end{array}$ & $\begin{array}{c}\text { Kebutuhan } \\
\text { Tulangan }\end{array}$ & $\begin{array}{c}\mathrm{A}_{\mathrm{spsg}} \\
\left(\mathrm{mm}^{2}\right)\end{array}$ & $\begin{array}{c}\phi V \mathrm{Vn} \\
(\mathrm{kN} . \mathrm{m})\end{array}$ \\
\hline \multirow{2}{*}{$13 / 30$} & Tump. & Neg. & 32,01 & 2 D10-130 & 773,32 & 75,78 \\
& & Pos. & 3,00 & 2 D10-130 & 773,2 & 75,78 \\
$13 / 250$ & Tump. & Neg. & 8,24 & 2 D10-100 & 1005,3 & 76,44 \\
& & Pos. & 0,53 & 2 D10-100 & 1005,3 & 76,44 \\
\hline
\end{tabular}

c. Perencanaan elemen kolom

Analisis perencanaan $\mathrm{K} 1, \mathrm{~K} 2$ dan $\mathrm{K} 3$ yang ditinjau adalah kolom dengan gaya dalam maksimum yang dapat dilihat pada tabel 5 . Luas tulangan yang dibutuhkan pada kolom dapat dilihat pada Tabel 11.

Tabel 11. Luas Tulangan Elemen Kolom Rencana

\begin{tabular}{ccc}
\hline $\begin{array}{c}\text { Tipe } \\
\text { Kolom }\end{array}$ & $\begin{array}{c}\text { Tulangan } \\
\text { Longitudinal } \\
\left(\mathrm{mm}^{2}\right)\end{array}$ & $\begin{array}{c}\text { Tulangan } \\
\text { Longitudinal } \\
\left(\mathrm{mm}^{2} / \mathrm{mm}\right)\end{array}$ \\
\hline $\mathrm{K} 1.1$ & 766 & 0 \\
$\mathrm{~K} 2.1$ & 1178 & 0 \\
$\mathrm{~K} 3.1$ & 1256 & 0 \\
\hline
\end{tabular}

Analisis elemen kolom rencana menggunakan program spColumn. Kapasitas aksial dan lentur elemen kolom rencana dapat dilihat pada tabel 12 serta kapasitas geser elemen kolom rencana dapat dilihat pada tabel 13 .

Tabel 12. Kapasitas Aksial dan Lentur Elemen Kolom Rencana

\begin{tabular}{cccccccc}
\hline \multirow{2}{*}{$\begin{array}{c}\text { Tipe } \\
\text { Kolom }\end{array}$} & \multicolumn{4}{c}{ Analisis struktur } & \multicolumn{2}{c}{ Kapasitas struktur } \\
\cline { 2 - 8 } & Tul. & $\begin{array}{c}\mathrm{Pu} \\
(\mathrm{KN})\end{array}$ & \multicolumn{2}{c}{$\mathrm{Mu}(\mathrm{kN} . \mathrm{m})$} & $\begin{array}{c}\phi P n \\
(\mathrm{KN})\end{array}$ & \multicolumn{1}{c}{$\phi \mathrm{Mn}(\mathrm{kN} . \mathrm{m})$} \\
\hline K1.1 & 8 D10 & 180,12 & 3,10 & 5,69 & 494,2 & 6,02 & 11 \\
K2.1 & 13D10 & 231,80 & 15,54 & 20,10 & 824,1 & 25,18 & 32 \\
K3.1 & $18 D 10$ & 167,68 & 20,68 & 22,96 & 1236,3 & 40,13 & 4 \\
\hline
\end{tabular}

Diagram interaksi kolom pipih rencana dengan aplikasi program spColumn dapat dilihat pada gambar 9, 10 dan 11.

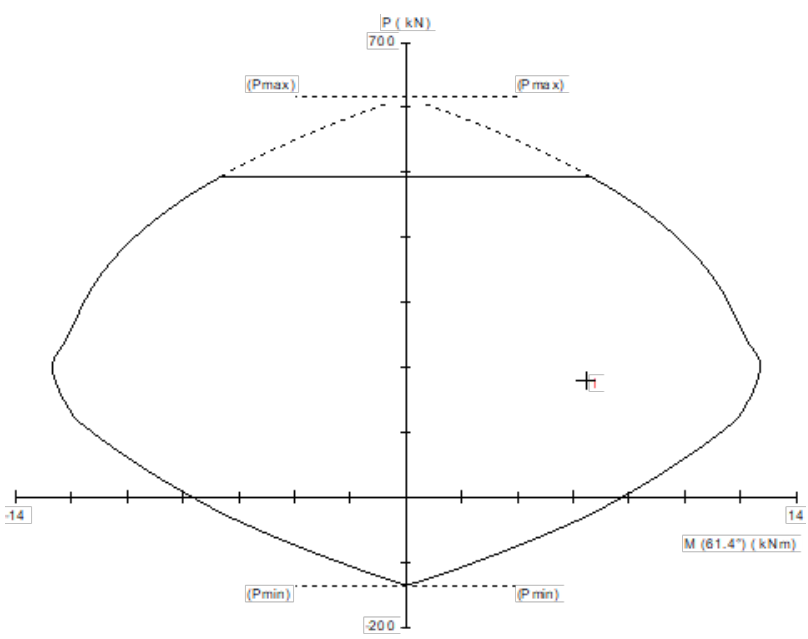

Gambar 9. Diagram Interaksi Kolom Pipih K1.1
Dari hasil analisis kolom pipih K1.1 diperoleh gaya aksial terfaktor $\mathrm{Pu}<\phi \mathrm{Pn}$ dan momen lentur terfaktor $\mathrm{Mu}<$ momen nominal $\phi \mathrm{Mn}$ sehingga dapat dinyatakan bahwa kolom pipih K1.1 mampu menahan beban aksial dan momen lentur. Dengan nilai $\phi P n$ yang sama antara kolom pipih K.1 dan K.1.1, terjadi peningkatan gaya aksial ultimit sebesar $35,92 \%$, namum tetap diperoleh gaya aksial terfaktor $\mathrm{Pu}<\phi \mathrm{Pn}$.

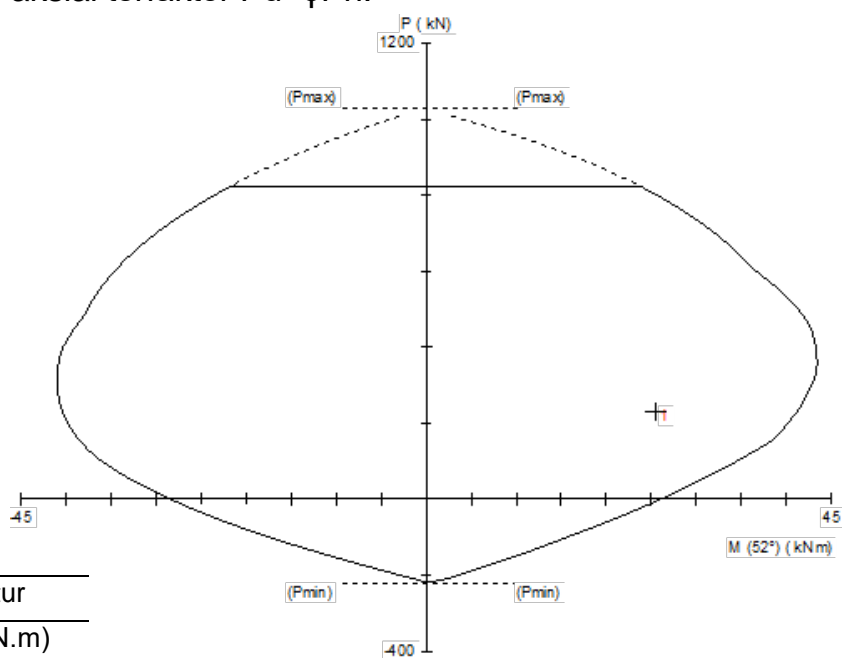

Gambar 10. Diagram Interaksi Kolom Pipih K2.1 11,06

Dari hasil analisis kolom pipih K2.1 terjadi 44,55ingkatan gaya aksial ultimit sebesar 30,06\%, namum tetap diperoleh gaya aksial terfaktor $\mathrm{Pu}<\phi P n$ sehingga dapat dinyatakan bahwa kolom pipih K2.1 mampu menahan beban aksial yang terjadi.

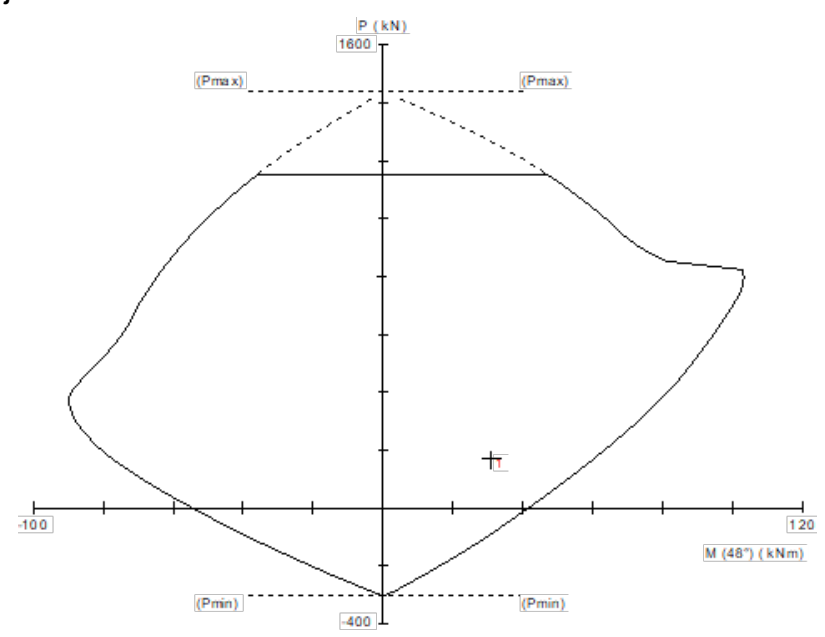

Gambar 11. Diagram Interaksi Kolom Pipih K3.1 
Tabel 13. Kapasitas Geser Elemen Kolom Rencana

\begin{tabular}{cccccc}
\hline \multirow{2}{*}{ Tipe Kolom } & \multirow{2}{*}{ Tulangan Sengkang } & \multicolumn{2}{c}{ Analisis struktur } & \multicolumn{2}{c}{ Kapasitas struktur } \\
\cline { 3 - 6 } & & $\mathrm{X}$ & $\mathrm{Y}(\mathrm{kN})$ & $\mathrm{X}$ & $\mathrm{Y}$ \\
\hline K1.1 & $\varnothing 8-150$ & 1,52 & 3,10 & 76,75 & 38,11 \\
K2.1 & $\varnothing 8-150$ & 7,53 & 3,66 & 75,26 & 75,26 \\
K3.1 & $\varnothing 8-150$ & 22,75 & 18,62 & 72,87 & 126,48 \\
\hline
\end{tabular}

Dari hasil perhitungan elemen existing dan rencana memenuhi persayarat SNI 2847: 2013 pasal 9.1.1 dimana komponen struktur memenuhi gaya aksial terfaktor $\mathrm{Pu}<\phi \mathrm{Pn}$, momen lentur terfaktor Mu<momen nominal $\phi \mathrm{Mn}$ dan gaya geser terfaktor Vu<gaya geser nominal $\phi \vee n$.

Setelah dilakukan perencanaan pada seluruh elemen struktur rencana, diperoleh semua elemen rencana yang terdiri dari pelat lantai, balok dan kolom memenuhi persyaratan SNI 2847: 2013, hal ini sama dengan penelitian yang telah dilakukan oleh Kasim, S., dkk, (2016).

Perhitungan kekuatan momen nominal (Mn) untuk semua kondisi pada balok memenuhi persyaratan Mu $\leq \phi M n$ dan juga kekuatan geser nominal (Vn) pada balok untuk semua kondisi memenuhi persyaratan $\mathrm{Vu}<\phi \vee \mathrm{n}$. Pengecekan kekuatan elemen struktur pelat lantai dinyatakan aman karena nilai $\mathrm{Mu} \leq \phi M n$. Untuk rasio tulangan memenuhi persyaratan SNI 2847: 2013 pasal 10.5.1 dimana $\rho_{\min }<\rho<\rho_{\max }$.

Pengecekan kekuatan elemen struktur balok aman terhadap kapasitas lentur dimana $M u \leq \phi M n$. Untuk rasio tulangan yang digunakan memenuhi persyaratan SNI 2847: 2013 pasal 10.5.1 dimana $\rho_{\min }<\rho<\rho_{\max }$, kapasitas geser telah memenuhi persyaratan SNI 2847: 2013 pasal 11.1 yaitu $\mathrm{Vu} \leq \phi \vee \mathrm{n}$.

Perhitungan kekuatan penampang kolom K1.1, K2.1 dan K3.1 menggunakan aplikasi spColumn V6.0 dengan menginput data-data berupa material, gaya aksial dan momen, kombinasi beban pada kolom berdasarkan SNI 2847: 2013 pasal 10.3.6 desain beban aksial dinyatakan aman karena Pu $\leq \phi P n$ hasil output yang dilihat pada diagram interaksi kolom K1.1, K2.1 dan K3.1 dapat memikul beban yang bekerja pada kolom sesuai dengan hasil penelitian Limbongan, S., dkk (2016) dimana dimensi kolom akan berbanding terbalik dengan simpangan antar lantai yang terjadi. Sehingga pemanfaatan kolom pipih pada Perumahan Villa Anggrek dapat digunakan dan mampu memikul beban yang bekerja (Roring, Y., dkk, 2016 serta Wonlele, T., 2016). Akan tetapi perlu diperhatikan akibat dari penggunaan dimensi kolom yang rata sama dinding maka rentan terhadap tekuk.

\section{KESIMPULAN}

Dari hasil analisis dapat disimpulkan bahwa kapasitas struktur existing dan rencana yang menggunakan struktur kolom pipih beton bertulang pada perumahan Villa Anggrek Kota Pekanbaru aman untuk menerima kombinasi beban sesuai SNI 2847-2013. Serta pemanfaatan kolom pipih dengan dimensi kolom dibuat rata sama dinding sehingga akan lebih baik di pandang dari segi estetika namun tetap mampu memikul beban yang bekerja.

\section{UCAPAN TERIMA KASIH}

Ucapan terima kasih diberikan kepada Lembaga Penelitian dan Pengabdian Kepada Masyarakat Universitas Lancang Kuning dan Program Studi Teknik Sipil Universitas Lancang Kuning yang telah memberikan dukungan dalam penyelesaian penelitian ini.

\section{REFERENSI}

Asroni, A. (2010). Balok dan Pelat Beton Bertulang. Graha Ilmu. Yogyakarta.

Badan Standar Nasional. (2013). SNI 1727-2013 Beban Minimum Untuk Perancangan Bangunan Gedung dan Struktur Lain. Jakarta.

Badan Standar Nasional. (2013). SNI 2847-2013 Persyaratan Beton Struktural Untuk Bangunan Gedung. Jakarta.

Dewobroto, W. (2013). Komputer Rekayasa Struktur dengan SAP2000. Lumina Press. Jakarta.

Imran, I. dan Ediansjah, Z. (2014). Perencanaan Dasar Struktur Beton Bertulang. ITB Press. Bandung.

Limbong, S. dkk. (2016). Analisis Struktur Beton Bertulang Kolom Pipih pada Gedung Bertingkat. Jurnal Sipil Statik. Vol. 4. No. 8. pp.409-508. ISSN: 2337-6732.

Rifa'i, M. L. Dkk. (2014). Evaluasi Kinerja Struktur Pada Gedung Bertingkat Dengan Analisis Dinamik Respon Spektrum Menggunakan Software ETABS (Studi Kasus : Hotel di Wilayah Karanganyar). Jurnal Teknik Sipil. Vol. 2. No. 1. pp. 32-39. ISSN : 2354-8630. 
Roring, Y. Dkk. (2016). Respon Dinamis Struktur Bangunan Beton Bertulang Bertingkat Banyak Dengan Kolom Berbentuk Pipih. Jurnal Teknik Sipil. Vol.4. No.10. pp. 649555. ISSN : 2337-6732.

Setiawan, A. (2016). Perancangan Struktur Beton Bertulang Berdasarkan SNI 2847:2013,. Erlangga. Jakarta.

Wonlele, T. (2016). Perencanaan Kolom Pipih dan Kolom Non Simetris Untuk Bangunan Bertingkat Rendah di Kota Kupang. Jurnal Teknik Sipil. Vol. 1. No. 1. pp 83-94. ISSN : 2621-9786. 